Gynecol. obstet. Invest. 1988;25:I-VI

\title{
Contents, Vol. 25, 1988
}

\section{Contents Vol. 25,1988}

No. 1 Original Paper

Combined Pregnancy and Starvation Effects on Rat Tissue Iron, Zinc and Copper Contents

Romeu, A.; Arola, L 1

Perinatal Development of Angiotensin - Converting Enzyme in the Rat's Blood

Peleg, E.; Peleg, D.; Yaron, A.; Goldman, J.A.; Rosenthal, T

Ultrasonographic Identification and Measurement of the Human Fetal Adrenal Gland in utero: Clinical Application

Hata, K.; Hata, T.; Kitao, M 16

Phospholipase C Activity and Phosphatidylinositol in Amniotic Fluid. A Possible Contribution of the Fetus to the Initiation of Human Parturition

Takahashi, H.; Murata, M.; Maki, M 23

Antibodies against Enterotoxigenic Escherichia coli in the Colostrum Isolated from Infants with Diarrhea

Kletter, Y.; Goldhar, J.; Gutman, R.; Fried, D.; Zakut, H 31

Smoking Exerts a Ketogenic Influence in Diabetic Pregnancy

Nylund, L.; Lunell, N.O.; Persson, B.; Fredholm, B.B.; Lagercrantz, H

Postcesarean Section Plasma Fibronectin Levels

Bawdon, R.E.; Davis, L.L 38

Effects of Prazosin and Indomethacin on the $\alpha$-Adrenergic Stimulation of Rabbit Myometrium

Barss, V.A.; Phillippe, M.; Valles, L 42

Descriptive Light and Electron Microscopy of Normal and Clue-Cell-Positive Discharge van der Meijden, W.I.; Koerten, H.; van Mourik, W.; de Bruijn, W.C

Tamoxifen and Natural Progesterone as Supplements to Low-Dose Postmenopausal Estrogen Therapy

Kauppila, A.; Kivinen, S.; Sternbäck, F.; Vihko, R.; Vuopala, S 58

Serum Levels of Vitamin A, E, and Selenium in Women with Lichen sclerosus of the Vulva Treated with Etretinate

Romppanen, U.; Tuimala, R.; Ellmén, J.; Koskinen, T.; Pyykkö, K 66

Case Report

Endometriosis in a Patient with Rokitansky-Kuster-Hauser Syndrome

Acien, P.; Lloret, M.; Chehab, H 70

IV

Contents

No. 2 Original Paper

Characteristics of Action Potentials and Contractions Evoked by Electrical-Field Stimula tion of Pregnant Human Myometrium

Kawarabayashi, T.; Kishikawa, T.; Sugimori, H 
Fetal Heart Rate Beat-to-Beat Variability in Uncomplicated Labor

Zimmer, E.Z.; Divon, M.Y.; Vadasz, A 80

Maternal Whole Blood Viscosity in Pregnancy Hypertension

Zondervan, H.A.; Oosting, J.; Smorenberg-Schoorl, M.E.; Treffers, P.E 83

Changes in Pancreatic B Cell Function during Late Pregnancy, Early Lactation and Postlactation

Hubinont, C.J.; Balasse, H.; Dufrane, S.P.; Leclercq-Meyer, V.; Sugar, J.; Schwers, J.;

Malaisse, W.J 89

Abortion Risk in Chorionic Villus Sampling. Evaluation in Elective Termination of Pregnancy

Flores-Genger, H.; Husslein, P.; Knogler, W.; Metka, M.; Wagenbichler, P.; Scholz, P.;

Schnedl, W 96

Alterations in Vitamin D Metabolites and Minerals in Diabetic Pregnancy

Kuoppala, T 99

Ritodrine Infusion at Term: Effects on Maternal and Fetal Prostacyclin, Thromboxane and

Prostaglandin Precursor Fatty Acids

Ekblad, U.; Erkkola, R.; Uotila, P.; Kanto, J.; Palo, P 106

Trace Elements during 2 Years' Oral Contraception with Low-Estrogen Preparations

Liukko, P.; Erkkola, R.; Pakarinen, P.; Järnström, S.; Näntö, V.; Grönroos, M 113

Progestagen-Dependent Effect on Some Plasma Proteins during Oral Contraception

Liukko, P.; Erkkola, R.; Bergink, E.W 118

Use of Highly Evacuated Redon Drains after Gynecologic Laparotomies

Grillo, M.; Riedel, H.-H.; Lehmann-Willenbrock, E.; Holler, Ch 123

Absence of Immunoreactive Luteinizing Hormone following Gonadotropin-Releasing Hor mone Agonist Therapy in Women with Endometriosis

Bischof, P.; Herrmann, W.L 130

Correlation between Steroid Hormone Receptors, Histological and Clinical Parameters in Ovarian Carcinoma

Anderl, P.; Fuith, L.C.; Daxenbichler, G.; Marth, C; Dapunt, 0135

Case Reports

Severe EPH Gestosis Accompanied by HELLP Syndrome and Acute Renal Failure

Zakut, H.; Adler, M 141

Iatrogenic Mechanical Ileus due to Over-Distended Uterus

Dan, U.; Rabinovici, J.; Koller, M.; Barkai, G.; Mashiach, S

143

No. 3 Original Paper

Effect of Protein Synthesis Inhibitors and Metabolic Blockers on the Production of Placental Proteins by the in vitro Perfused Human Placenta

Bersinger, N.A.; Malek, A.; Benz, B.; Keller, P.J.; Schneider, H

Interexaminer Variability of Fetal Doppler Velocity Waveforms

Nienhuis, S.J.; van Vugt, J.M.G.; Hoogland, H.J.; Ruissen, C.J.; de Haan, J

152

Longitudinal Study of Plasma Lipids and Lipoprotein Cholesterol in Normal Pregnancy and Puerperium

Jimenez, D.M.; Pocovi, M.; Ramon-Cajal, J.; Romero, M.A.; Martinez, H.; Grande, F. 158

Contents V

NK Cell Activity and Estrogen Hormone Levels during Normal Human Pregnancy

Gabrilovac, J.; Zadjelovic, J.; Osmak, M.; Suchanek, E.; Zupanovic, Z.; Boranic, M. . 165

Obstetrical Characteristics of Loss of End-Diastolic Velocities in the Fetal Aorta and/or 
Umbilical Artery Using Doppler Ultrasound

Arabin, B.; Siebert, M.; Jimenez, E.; Saling, E

Prediction of Sepsis Neonatorum following a Full-Term Pregnancy

Ahldén, S.; Andersch, B.; Stigsson, L.; Olegård, R 181

Quantification of the Fetal Heart Rate Variability by Spectral Analysis in Growth-Retarded

Fetuses

Breborowicz, G.; Moczko, J.; Gadzinowski, J 186

Ovarian Morphology in Patients with Polycystic Ovaries and in an Age-Matched Reference

Material. A Statistical Evaluation of 149 Cases

Lunde, O.; Hoel, P.S.; Sandvik, L 192

Ultrasonic Evaluation of Fallopian Tube Carcinoma

Yamamoto, K.; Katoh, S.; Nakayama, S.; Kijima, S.; Takahashi, K.; Murao, F.; Kitao, M. 202

Short Communications

Relaxin and Human Chorionic Gonadotropin Concentrations in Blood Serum during the

First Trimester of Normal and Pathological Pregnancy

Seeger, H.; Zwirner, M.; Voelter, W.; Lippert, T.H 209

Changes in Erythrocyte and Plasma Zinc Concentrations in Pregnancy

Lao, T.T.H.; Chin, R.K.H.; Mak, Y.T.; Swaminathan, R 213

No. 4 Original Paper

Birth Order in Delivery of Twins

Nakano, R.; Takemura, H 217

Measurement of T4, T3 and Reverse T3 Levels, Resin T3 Uptake, and Free Thyroxin Index in Blood from the Intervillous Space of the Placenta, in Maternal Peripheral Blood, and in the Umbilical Artery and Vein of Normal Parturients and Their Conceptuses

Silva de Sá, M.F.; Maranhâo, T.M.O.; Iasigi, N.; Maciel, R.M.B.; Meirelles, R.S. ... 223

Placental Protein 21. Localization in Human Placenta and Concentrations in the Body

Fluids of Men and Nonpregnant and Pregnant Women

Takayama, M.; Isaka, K.; Ogawa, T.; Funayama, H.; Yamabe, S.; Soma, H.; Bohn, H. 230 Blood

Pressure Monitoring from a Biostatistical and Clinical Viewpoint for Predicting

Fetal Distress in Preeclamptic Pregnancy

Cugini, P.; Leone, G.; Antonicoli, S.; Lucia, P.; Letizia, C; Di Palma, L.; Cogliati, A.;

Moscarini, M.; Caserta, D 239

Effect of Autonomic Nervous System Blockade and Acute Asphyxia on Heart Rate Variability in the Fetal Rat

Syutkina, E.V 249

Effects of Human Calcitonin Gene-Related Peptide and Substance P on Human Intracer-

vical Arteries

Hansen, V.; Schifter, S.; Allen, J.; Maigaard, S.; Forman, A258

Reduced B2-Adrenoceptor Sensitivity in Normal Pregnancy but Not in Pregnancy-Induced Hypertension

Nisell, H.; Martinsson, A.; Hjemdahl, P 262

Occurrence of CA 125 and CA 19-9 Tumor-Associated Antigens in Sera of Patients with

Gynecologic, Trophoblastic, and Colorectal Tumors

Göcze, P.M.; Szabó, D.G.; Than, G.N.; Csaba, I.F.; Krommer, K.F 268

VI

Contents 
Case Reports

Succenturiate Placenta Diagnosed by Ultrasound

Hata, K.; Hata, T.; Aoki, S.; Takamori, H.; Takamiya, O.; Kitao, M273

Anaphylactoid Reaction to Oxytocin during Cesarean Section

Kawarabayashi, T.; Narisawa, Y.; Nakamura, K; Sugimori, H.; Oda, M.; Taniguchi, Y. 277

Announcement

279

Author Index 280

Subject Index 281 